\title{
An evaluation of ambient ammonia concentrations over southern Ontario simulated with different dry deposition schemes within STILT-Chem v0.8
}

\author{
D. Wen ${ }^{1}$, L. Zhang ${ }^{2}$, J. C. Lin ${ }^{1,3}$, R. Vet ${ }^{2}$, and M. D. Moran ${ }^{2}$ \\ ${ }^{1}$ Waterloo Atmosphere-Land Interactions Research Group, Department of Earth and Environmental Sciences, \\ University of Waterloo, Canada \\ ${ }^{2}$ Air Quality Research Division, Science and Technology Branch, Environment Canada, Canada \\ ${ }^{3}$ Department of Atmospheric Sciences, University of Utah, USA \\ Correspondence to: J. C. Lin (john.lin@utah.edu)
}

Received: 6 October 2013 - Published in Geosci. Model Dev. Discuss.: 29 November 2013

Revised: 1 April 2014 - Accepted: 7 April 2014 - Published: 28 May 2014

\begin{abstract}
A bidirectional air-surface exchange scheme for atmospheric ammonia was incorporated into the Stochastic Time-Inverted Lagrangian Transport air quality model (STILT-Chem v0.8). STILT-Chem v0.8 was then applied to simulate atmospheric ammonia concentrations at 53 measurement sites in the province of Ontario, Canada for a sixmonth period from 1 June to 30 November 2006. In addition to the bidirectional scheme, two unidirectional dry deposition schemes were tested. Comparisons of modeled ammonia concentrations against observations show that all three schemes can reasonably predict observations. For sites with low observed ammonia concentrations, the bidirectional scheme clearly overestimated ammonia concentrations during crop-growing season. Although all three schemes tended to underestimate ammonia concentrations after mid-October and for sites with elevated observed concentrations, mainly due to underestimated $\mathrm{NH}_{3}$ emission inventory after midOctober and/or underestimated emission potentials for those sites, the bidirectional scheme performed better because of its introduction of compensation points into the flux calculation parameterization. In addition to uncertainties in the emission inventory, the results of additional sensitivity tests suggest that uncertainties in the input values of emission potentials in the bidirectional scheme greatly affect the accuracy of modeled ammonia concentrations. The use of much larger emission potentials in the bidirectional scheme and larger anthropogenic $\mathrm{NH}_{3}$ emission after mid-October than provided in the model emissions files is needed for accurate prediction of elevated ammonia concentrations at intensive agricultural locations.
\end{abstract}

\section{Introduction}

As the primary basic gas in the atmosphere, atmospheric ammonia $\left(\mathrm{NH}_{3}\right)$ plays an important role in several biogeochemical processes (Seinfeld and Pandis, 2006). It acts as a major agent in neutralizing acids in the atmosphere and substantially contributes to fine particulate matter $\left(\mathrm{PM}_{2.5}\right)$ concentrations, which have impacts on air quality, acid deposition, atmospheric visibility, and climate. For example, human morbidity has been shown to increase linearly with $\mathrm{PM}_{2.5}$ concentrations (Pope et al., 2009), and excessive deposition of atmospheric $\mathrm{NH}_{3}$ and ammonium may lead to soil acidification and damage to sensitive species and ecosystem health (Morris, 1991; Van Bremen et al., 1982).

Unlike most gas-phase atmospheric species, which are predominantly either deposited to or emitted from the surface, $\mathrm{NH}_{3}$ is a semi-volatile species and exhibits bidirectional exchange between the atmosphere and the Earth's surface. However, dry deposition and emission of $\mathrm{NH}_{3}$ are simulated entirely separately in most atmospheric $\mathrm{NH}_{3}$ modeling studies (Simpson et al., 2012; Vieno et al., 2010; Geels et al., 2012). Such a decoupled treatment of these two processes is less realistic than a combined, bidirectional, gradientdriven flux model. Simulations with separate representations of emission and dry deposition likely underestimate ambient $\mathrm{NH}_{3}$ concentrations. Thus, the development of bidirectional modeling of $\mathrm{NH}_{3}$ is important since the bidirectional approach is responsive to combined changes of these two processes and allows for more accurate estimation of surface fluxes. Significant efforts have been made in the past two 
decades to develop bidirectional $\mathrm{NH}_{3}$ flux models (Sutton et al., 1998; Nemitz et al., 2001; Wu et al., 2009; Cooter et al., 2010; Wichink Kruit et al., 2010, 2012; Zhang et al., 2010).

Most existing bidirectional flux models for $\mathrm{NH}_{3}$ were parameterized for applications at canopy scales (Flechard et al., 2013). Only a few models were developed for implementation in regional-scale air quality models due to the lack of required input parameters over a large number of different land-use categories (Wichink Kruit et al., 2010, 2012; Cooter et al., 2010, 2012; Bash et al., 2013; Pleim et al., 2013). For example, required inputs of ground and stomatal emission potentials are generally not measured at regional scales or not explicitly calculated in regional-scale models. Zhang et al. (2010) developed a bidirectional exchange model for $\mathrm{NH}_{3}$ that can be easily implemented in any regional-scale air quality model: the required inputs of stomatal and ground emission potentials were empirically derived for different landuse categories based on an extensive literature review.

Although bidirectional exchange models of $\mathrm{NH}_{3}$ are more mechanistically realistic in principle, few studies have examined their actual performances against unidirectional dry deposition models at multiple measurement sites with a variety of different levels of $\mathrm{NH}_{3}$ (Wichink Kruit et al., 2012). In this study, the bidirectional exchange scheme of Zhang et al. (2010) was implemented in the Stochastic Time-Inverted Lagrangian Transport air quality model (STILT-Chem v0.8). The model was then used to simulate $\mathrm{NH}_{3}$ concentrations at 53 measurement sites in southern Ontario, Canada, first with the bidirectional scheme and then with two unidirectional dry deposition schemes that had already been included in the model. The main objective of this study was to assess the performances of these three dry deposition schemes in atmospheric $\mathrm{NH}_{3}$ modeling using a detailed data set of $\mathrm{NH}_{3}$ measurements. The uncertainties associated with using predefined emission potentials in the bidirectional scheme were also examined.

\section{Model description}

\subsection{STILT-Chem for $\mathrm{NH}_{3}$}

STILT-Chem v0.8 was employed in this study to simulate emissions, transport, transformation, and deposition of atmospheric $\mathrm{NH}_{3}$ as well as other key atmospheric species. STILT-Chem (Wen et al., 2012, 2013) is a stochastic Lagrangian air quality model developed from the Stochastic Time-Inverted Lagrangian Transport model (STILT; see http: //www.stilt-model.org) (Lin et al., 2003). A STILT-Chem simulation begins with a stochastic back-trajectory simulation, followed by forward calculations that determine tracer concentrations along the generated back trajectories. In the back-trajectory simulation, numerous virtual particles, each representing an air parcel, are released from a receptor and transported backward in time for a specific period. Each particle is transported by both interpolated mean wind fields as well as stochastic velocities representing turbulent eddies. After back trajectories have been calculated, the concentrations of modeled species are initialized at the endpoint of each back trajectory using values output from a global chemical transport model. The initial parcel concentrations are then evolved forward in time along each trajectory to take into consideration the influences of emissions, deposition, and chemical transformation. STILT-Chem uses the Carbon Bond IV (CB4) gas-phase chemical mechanism (Gery et al., 1989) to simulate the time evolution of the concentrations of a variety of gas-phase species in the atmosphere while using an additional chemistry module to simulate the multiphase species involved in the key atmospheric reactions of atmospheric $\mathrm{NH}_{3}$ and ammonium. A comprehensive description of the treatment of emission, transport, transformation, and deposition of atmospheric $\mathrm{NH}_{3}$ and ammonium in STILTChem can be found in Wen et al. (2013).

\subsection{Two unidirectional dry deposition schemes}

\subsubsection{Wesely dry deposition scheme}

A dry deposition scheme based on the work of Wesely (1989) (hereafter referred to as WDD) was used as the default in STILT-Chem to compute dry deposition velocities of the modeled gaseous and aerosol species (Draxler and Hess, 1997). The WDD scheme estimates the dry deposition velocity by utilizing the resistance analogy method (Fig. 1), in which each species-specific dry deposition velocity $\left(v_{\mathrm{d}}\right.$ in $\mathrm{m} \mathrm{s}^{-1}$ ) is calculated as (Draxler and Hess, 1997)

$v_{\mathrm{d}}=\left(R_{\mathrm{a}}+R_{\mathrm{b}}+R_{\mathrm{c}}+R_{\mathrm{a}} R_{\mathrm{b}} v_{\mathrm{g}}\right)^{-1}+v_{\mathrm{g}}$,

where $R_{\mathrm{a}}\left(\mathrm{s} \mathrm{m}^{-1}\right)$ is the aerodynamic resistance between a specified height and the surface, $R_{\mathrm{b}}\left(\mathrm{s} \mathrm{m}^{-1}\right)$ is the quasilaminar sublayer resistance, and $R_{\mathrm{c}}\left(\mathrm{s} \mathrm{m}^{-1}\right)$ is the bulk canopy surface resistance and is zero for particles. $R_{\mathrm{a}}$ $\left(\mathrm{s} \mathrm{m}^{-1}\right)$ is computed using the friction velocity and the Businger stability functions for the surface layer; $R_{\mathrm{b}}\left(\mathrm{s} \mathrm{m}^{-1}\right)$ is computed in different ways over land and sea: over the land, it is parameterized through the friction velocity and the diffusivity characteristics of the gas and over the sea it is assumed to be small and only limited by the atmospheric resistance (Slinn and Slinn, 1980; Wesely, 1989; Draxler and Hess, 1997). $v_{\mathrm{g}}\left(\mathrm{m} \mathrm{s}^{-1}\right)$, gravitational settling velocity for particles is calculated as (Van der Hoven, 1968),

$v_{\mathrm{g}}=d_{\mathrm{p}}^{2} g\left(\rho_{\mathrm{g}}-\rho\right)(18 \mu)^{-1}$,

where $d_{\mathrm{p}}(\mathrm{m})$ is the particle diameter, $g$ is the gravity of Earth $\left(9.801 \mathrm{~m} \mathrm{~s}^{-2}\right), \rho\left(\mathrm{g} \mathrm{m}^{-3}\right)$ is air density, $\rho_{\mathrm{g}}\left(\mathrm{g} \mathrm{m}^{-3}\right)$ is particle density, and $\mu$ is the dynamic viscosity of air $\left(0.01789 \mathrm{~g} \mathrm{~m}^{-1} \mathrm{~s}^{-1}\right)$. Note that $v_{\mathrm{g}}$ is zero for gases. 


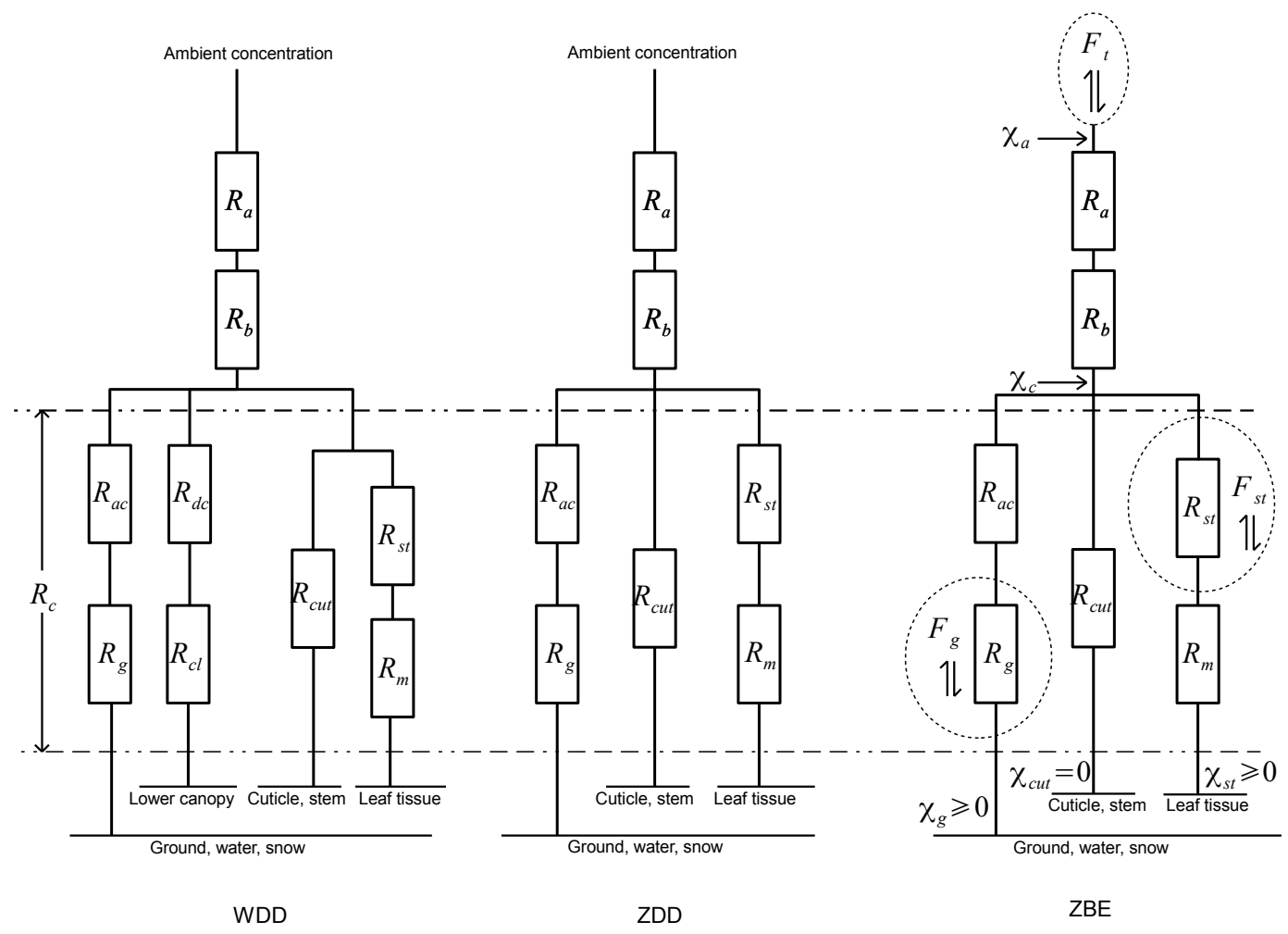

Figure 1. Diagrammatic representation of the WDD, ZDD, and ZBE schemes. Resistances include the aerodynamic resistance $\left(R_{\mathrm{a}}\right)$, the quasi-laminar sublayer resistance above the canopy $\left(R_{\mathrm{b}}\right)$, and the overall canopy resistance $\left(R_{\mathrm{C}}\right)$. $R_{\mathrm{c}}$ can be decomposed into stomatal resistance $\left(R_{\mathrm{St}}\right)$, mesophyll resistance $\left(R_{\mathrm{m}}\right)$, in-canopy aerodynamic resistance $\left(R_{\mathrm{ac}}\right)$, soil resistance $\left(R_{\mathrm{g}}\right)$, cuticle resistance $\left(R_{\mathrm{cut}}\right)$, lower canopy resistance $\left(R_{\mathrm{cl}}\right)$, and resistance for the gas transfer affected by buoyant convection in the canopy $\left(R_{\mathrm{dc}}\right)$. $F_{\mathrm{t}}$ is overall flux at a reference height above the canopy. $F_{\mathrm{st}}$ and $F_{\mathrm{g}}$ are bidirectional fluxes through stomata and above the soil surface, respectively. $\chi_{\mathrm{a}}$ is the ambient concentration at the reference height. $\chi_{\mathrm{c}}$ is the concentration at the top of canopy. $\chi_{\mathrm{st}}$ and $\chi_{\mathrm{g}}$ are the stomatal and soil compensation points, respectively.

$R_{\mathrm{c}}$ depends primarily upon a number of plant physiological and ground surface characteristics and is parameterized as (Wesely, 1989)

$$
\begin{aligned}
R_{\mathrm{c}}= & {\left[1 /\left(R_{\mathrm{st}}+R_{\mathrm{m}}\right)+1 / R_{\mathrm{cut}}+1 /\left(R_{\mathrm{dc}}+R_{\mathrm{cl}}\right)\right.} \\
& \left.+1 /\left(R_{\mathrm{ac}}+R_{\mathrm{g}}\right)\right]^{-1},
\end{aligned}
$$

where $R_{\mathrm{st}}\left(\mathrm{s} \mathrm{m}^{-1}\right)$ is the stomatal resistance, $R_{\mathrm{m}}\left(\mathrm{s} \mathrm{m}^{-1}\right)$ is the mesophyll resistance, $R_{\text {cut }}\left(\mathrm{s} \mathrm{m}^{-1}\right)$ is the upper-canopy leaf cuticle resistance, $R_{\mathrm{dc}}$ is the resistance to gas-phase transfer by convection, $R_{\mathrm{cl}}\left(\mathrm{s} \mathrm{m}^{-1}\right)$ is the lower canopy resistance, $R_{\mathrm{ac}}\left(\mathrm{s} \mathrm{m}^{-1}\right)$ is the canopy height and density factor resistance, and $R_{\mathrm{g}}\left(\mathrm{s} \mathrm{m}^{-1}\right)$ is the ground surface resistance. $R_{\mathrm{st}}$ is parameterized as

$R_{\mathrm{st}}=R_{i}$

$D_{\mathrm{hx}}\left[1+(200 /(G+0.1))^{2}\right]\left[400 /\left(T_{\mathrm{S}}\left(40-T_{\mathrm{S}}\right)\right)\right]$,

where $R_{i}\left(\mathrm{~s} \mathrm{~m}^{-1}\right)$ is the minimum resistance for water vapor, which depends upon season and land-cover, $D_{\mathrm{hx}}$ is the ratio of the diffusivity of water vapor to that of the pollutant, $G$ $\left(\mathrm{W} \mathrm{m}^{-2}\right)$ is the solar radiation reaching at the canopy, and $T_{\mathrm{S}}$ $\left({ }^{\circ} \mathrm{C}\right)$ is the surface air temperature in the canopy. For temperatures outside the $0-40{ }^{\circ} \mathrm{C}$ temperature range, $R_{\mathrm{st}}$ is set to a very large value. The other resistances $\left(R_{\mathrm{m}}, R_{\mathrm{cut}}, R_{\mathrm{dc}}\right.$, $R_{\mathrm{cl}}, R_{\mathrm{ac}}, R_{\mathrm{g}}$ ) depend primarily upon the effective (relative to $\mathrm{SO}_{2}$ ) Henry's constant and the specific reactivity of the pollutant. The parameterization of those resistances can be found in Draxler and Hess (1997).

\subsubsection{Zhang dry deposition scheme}

Another dry deposition scheme, based on the work of Zhang et al. $(2001,2003)$ (hereafter referred to as ZDD) has been added to STILT-Chem from version 0.7 as another option for calculating dry deposition of modeled gaseous and aerosol species (Wen et al., 2013). The ZDD scheme (Fig. 1) employs a methodology similar to the WDD scheme, but with an improved representation of non-stomatal resistance components and handling of seasonally dependent input parameters. The non-stomatal resistance components in the WDD scheme consist of in-canopy aerodynamic $\left(R_{\mathrm{ac}}\right)$, soil $\left(R_{\mathrm{g}}\right)$, and cuticle resistances $\left(R_{\text {cut }}\right)$ and were assigned constant values for a particular season and land type. In contrast, the 
ZDD scheme calculates these non-stomatal resistance components as a function of friction velocity, relative humidity, and canopy wetness, as well as biological factors, such as canopy type, leaf area index (LAI), and growing period, and is believed to be more realistic than using constant values. Substantial information on land-use-category specified input parameters including LAI and roughness length is adopted to reflect more realistic seasonal variations (Zhang et al., 2003). Note that the effects of low temperature and snow are also considered in the ZDD scheme to obtain more realistic cuticle and ground resistance in winter. The ZDD scheme, which is formulated for 26 land-use categories, can calculate dry deposition velocities for more than 30 gaseous species and 14 particulate species that are usually considered in regional air quality models. The scheme has been widely used in air quality models (e.g., Zhang et al., 2002; Alexander et al., 2005; Nopmongcol et al., 2012).

\subsection{Bidirectional $\mathrm{NH}_{3}$ air-surface exchange scheme}

In order to simulate bidirectional exchange of $\mathrm{NH}_{3}$ between the atmosphere and the Earth's surface, a bidirectional airsurface exchange scheme developed by Zhang et al. (2010) (hereafter referred to as ZBE) was implemented into STILTChem v0.8 in this study. The ZBE scheme (see Fig. 1) was developed for application in region-scale air quality models, in which stomatal and soil emission potentials are specified according to land-use category and season, based on an extensive review of measurement and model studies.

In this scheme, the overall vertical flux $F_{\mathrm{t}}\left(\mu \mathrm{g} \mathrm{m} \mathrm{m}^{-2} \mathrm{~s}^{-1}\right)$ at a reference height above the canopy can be calculated as

$F_{\mathrm{t}}=-\frac{\left(\chi_{\mathrm{a}}-\chi_{\mathrm{c}}\right)}{\left(R_{\mathrm{a}}+R_{\mathrm{b}}\right)}$,

where $\chi_{\mathrm{a}}\left(\mu \mathrm{g} \mathrm{m}^{-3}\right)$ is the $\mathrm{NH}_{3}$ air concentration at the reference height, and $\chi_{\mathrm{c}}\left(\mu \mathrm{g} \mathrm{m}^{-3}\right)$ is the $\mathrm{NH}_{3}$ air concentration at the canopy top and can be calculated as

$$
\begin{aligned}
\chi_{\mathrm{c}}= & \left(\frac{\chi_{\mathrm{a}}}{R_{\mathrm{a}}+R_{\mathrm{b}}}+\frac{\chi_{\mathrm{st}}}{R_{\mathrm{st}}+R_{\mathrm{m}}}+\frac{\chi_{\mathrm{g}}}{R_{\mathrm{ac}}+R_{\mathrm{g}}}\right) . \\
& \left(\frac{1}{R_{\mathrm{a}}+R_{\mathrm{b}}}+\frac{1}{R_{\mathrm{st}}+R_{\mathrm{m}}}+\frac{1}{R_{\mathrm{ac}}+R_{\mathrm{g}}}+\frac{1}{R_{\mathrm{cut}}}\right)^{-1},
\end{aligned}
$$

where $\chi_{\mathrm{st}}\left(\mu \mathrm{g} \mathrm{m}^{-3}\right)$ is the stomatal compensation point and $\chi_{\mathrm{g}}\left(\mu \mathrm{g} \mathrm{m}^{-3}\right)$ is the soil compensation point. The same formulas used in the ZDD scheme are used in the ZBE scheme to calculate all of the resistances in Eq. (6). All of those formulas can be found in the work of Zhang et al. (2003).

$\chi_{\text {st }}$ is defined chemically as the concentration at which there is both a thermodynamic equilibrium between $\mathrm{NH}_{3}$ in the liquid and gas phases and an acid-base equilibrium between $\mathrm{NH}_{4}^{+}$and $\mathrm{NH}_{3}$ in the liquid phase. $\chi_{\text {st }}$ can be either measured or calculated according to the formula (Nemitz et al., 2004)

$\chi_{\mathrm{st}}=1.703 \times 10^{10}\left(\frac{161500}{T_{\mathrm{st}}}\right) \exp \left(-\frac{10378}{T_{\mathrm{st}}}\right) \Gamma_{\mathrm{st}}$,

where $T_{\mathrm{st}}(\mathrm{K})$ is the temperature of the leaf stomata, and $\Gamma_{\mathrm{st}}$ is the stomatal emission potential at 1 atmosphere and is given by the expression (Nemitz et al., 2000)

$\Gamma_{\mathrm{st}}=\frac{\left[\mathrm{NH}_{4}^{+}\right]_{\mathrm{st}}}{\left[\mathrm{H}^{+}\right]_{\mathrm{st}}}$,

where $\left[\mathrm{NH}_{4}^{+}\right]_{\mathrm{st}}$ is the concentration of $\mathrm{NH}_{4}^{+}(\mathrm{mol} \mathrm{L}-1)$ in the apoplastic fluid (fluid in a tissue-level compartment formed by the continuum of cell walls of adjacent cells as well as the extracellular spaces). $\left[\mathrm{H}^{+}\right]_{\mathrm{st}}=10^{-\mathrm{pH}}$ is the stomatal concentration of $\mathrm{H}^{+}\left(\mathrm{mol} \mathrm{L}^{-1}\right)$ with the $\mathrm{pH}$ of the intercellular fluid at 1 atmosphere.

Similarly, $\chi_{\mathrm{g}}$ is calculated (Nemitz et al., 2004) using the formulas

$\chi_{\mathrm{g}}=1.703 \times 10^{10}\left(\frac{161500}{T_{\mathrm{g}}}\right) \exp \left(-\frac{10378}{T_{\mathrm{g}}}\right) \Gamma_{\mathrm{g}}$

$\Gamma_{\mathrm{g}}=\frac{\left[\mathrm{NH}_{4}^{+}\right]_{\mathrm{g}}}{\left[\mathrm{H}^{+}\right]_{\mathrm{g}}}$

where $T_{\mathrm{g}}(\mathrm{K})$ is the temperature of the ground surface, $\Gamma_{\mathrm{st}}$ is the stomatal emission potential, and $\left[\mathrm{NH}_{4}^{+}\right]_{\mathrm{g}}$ and $\left[\mathrm{H}^{+}\right]_{\mathrm{g}}$ are the concentrations of $\mathrm{NH}_{4}^{+}$and $\mathrm{H}^{+}\left(\mathrm{mol} \mathrm{L}^{-1}\right)$ in the ground cover.

In the ZBE scheme, a set of stomatal $\left(\Gamma_{\mathrm{st}}\right)$ and ground $\left(\Gamma_{\mathrm{g}}\right)$ emission potentials are specified (Table 1) as inputs for each land-use category using empirically derived values to generate $\chi_{\text {st }}$ and $\chi_{\mathrm{g}}$ using Eqs. (7) and (9), respectively. It should be noted that soil emission potential is a soil property and not a vegetation property and thus, assigning the soil emission potential values based on land-use category might not be appropriate in some cases. However, considering that a portion of soil emissions comes from decomposition of the litterfall from previous years, soil emission potentials could, to some extent, be related to land-use category. It is worth mentioning that other factors could dominate soil emissions, such as wet deposition at natural areas or fertilization over agricultural lands. In the latter case, soil emission could vary substantially both spatially and temporally, under which conditions the default values in Zhang et al. (2010) are likely to require adjustment. For example, Pleim et al. (2013) and Wichink Kruit et al. (2010) made use of information on agricultural activities to better estimate soil emissions. Knowing that soil properties are not available at regional scales in many cases, the approach proposed in Zhang et al. (2010) should be a reasonable first approximation. This is especially the case for non-managed forest canopies where soil emissions are much smaller than stomatal emissions. These values are based on an extensive review of model and measurement studies. As a result, they are generally representative of 
Table 1. Stomatal and ground emission potential inputs (dimensionless) by land-use category in the ZBE scheme (Zhang et al., 2010). Note that pairs of values correspond to low-N canopies and high-N canopies, respectively.

\begin{tabular}{|c|c|c|c|}
\hline & Land-use category & $\begin{array}{l}\text { Stomatal emission potential } \\
\qquad \Gamma_{\mathrm{st}}\end{array}$ & $\begin{array}{l}\text { Ground emission potential } \\
\qquad \Gamma_{\mathrm{g}}\end{array}$ \\
\hline 1 & Water & 0 & 0 \\
\hline 2 & Ice & 0 & 0 \\
\hline 3 & Inland lake & 0 & 0 \\
\hline 4 & Evergreen needleleaf trees & 300,3000 & 20,1000 \\
\hline 5 & Evergreen broadleaf trees & 300,3000 & 20,1000 \\
\hline 6 & Deciduous needleleaf trees & 300 & 200,2000 \\
\hline 7 & Deciduous broadleaf trees & 300,3000 & 200,2000 \\
\hline 8 & Tropical broadleaf trees & 300,3000 & 20,1000 \\
\hline 9 & Drought deciduous trees & 300,3000 & 500,2000 \\
\hline 10 & Evergreen broadleaf shrubs & 300,3000 & 20,1000 \\
\hline 11 & Deciduous shrubs & 300,3000 & 200,1000 \\
\hline 12 & Thorn shrubs & 300,3000 & 20,1000 \\
\hline 13 & Short grass and forbs & 300,3000 & 2000,200000 \\
\hline 14 & Long grass & 300,3000 & 2000,100000 \\
\hline 15 & Crops & 800 & 5000 \\
\hline 16 & Rice & 800 & 5000 \\
\hline 17 & Sugar & 800 & 5000 \\
\hline 18 & Maize & 800 & 5000 \\
\hline 19 & Cotton & 800 & 5000 \\
\hline 20 & Irrigated crops & 800 & 5000 \\
\hline 21 & Urban & 0 & 0 \\
\hline 22 & Tundra & 20 & 20 \\
\hline 23 & Swamp & 100 & 20 \\
\hline 24 & Desert & 0 & 0 \\
\hline 25 & Mixed wood forest & 300,3000 & 20,3000 \\
\hline 26 & Transitional forest & 300,3000 & 20,3000 \\
\hline
\end{tabular}

emission potentials for each land-use category and season. For forests and grasslands, two sets of $\Gamma_{\mathrm{st}}$ and $\Gamma_{\mathrm{g}}$ values are provided for the same land-use category to reflect different nitrogen contents - one for high- $\mathrm{N}$ canopies and the other for low-N canopies. For the atmospheric $\mathrm{NH}_{3}$ modeling studies in which anthropogenic $\mathrm{NH}_{3}$ emissions are used as an external input, following Eq. (6) the air concentration of $\mathrm{NH}_{3}$ at the canopy top $\chi_{\mathrm{c}}$ can be calculated as (Trebs et al., 2006)

$$
\begin{gathered}
\chi_{\mathrm{c}}=\left(\frac{\chi_{\mathrm{a}}}{R_{\mathrm{a}}+R_{\mathrm{b}}}+\frac{\chi_{\mathrm{st}}}{R_{\mathrm{st}}+R_{\mathrm{m}}}+\frac{\chi_{\mathrm{g}}}{R_{\mathrm{ac}}+R_{\mathrm{g}}}+F_{\mathrm{e}}\right) . \\
\left(\frac{1}{R_{\mathrm{a}}+R_{\mathrm{b}}}+\frac{1}{R_{\mathrm{st}}+R_{\mathrm{m}}}+\frac{1}{R_{\mathrm{ac}}+R_{\mathrm{g}}}+\frac{1}{R_{\mathrm{cut}}}\right)^{-1},
\end{gathered}
$$

where $F_{\mathrm{e}}\left(\mu \mathrm{g} \mathrm{m}^{-2} \mathrm{~s}^{-1}\right)$ is the $\mathrm{NH}_{3}$ anthropogenic emission flux from external inputs.

\section{Model simulations}

\subsection{Measurements used for simulation and comparison}

Detailed measurements of surface $\mathrm{NH}_{3}$ concentrations were carried out during the Southern Ontario Ammonia Passive
Sampler Survey (SOAPSS), which ran from 4 April 2006 to 27 March 2007 (Vet et al., 2008). The objective of SOAPSS was to measure ambient concentrations of $\mathrm{NH}_{3}$ at approximately 79 sites, mainly located in southern Ontario but also at a small number of Canadian sites outside of Ontario and US sites bordering the Great Lakes. The survey provided highly spatially resolved atmospheric $\mathrm{NH}_{3}$ concentration data, with distances between sites in southern Ontario of approximately $20 \mathrm{~km}$. The $\mathrm{NH}_{3}$ measurements were made using passive samplers and represent an integrated average of the nearsurface $\mathrm{NH}_{3}$ concentration over a one-week (before December 2006) or two-week (after November 2006) period. Out of all sites, 53 were selected as receptors and test sites in this study (Fig. 2), consisting of 39 agricultural sites and 14 forest sites. The other 26 sites, which were very close to transitions from one land-use type to another, were not used in this study because their land-use types cannot be assigned with certainty at the model grid scale due to insufficient resolution of the meteorological input.

\subsection{Simulation setup}

STILT-Chem v0.8 was used to simulate hourly $\mathrm{NH}_{3}$ concentrations at the 53 sites (Fig. 2) for a period from 1 June 

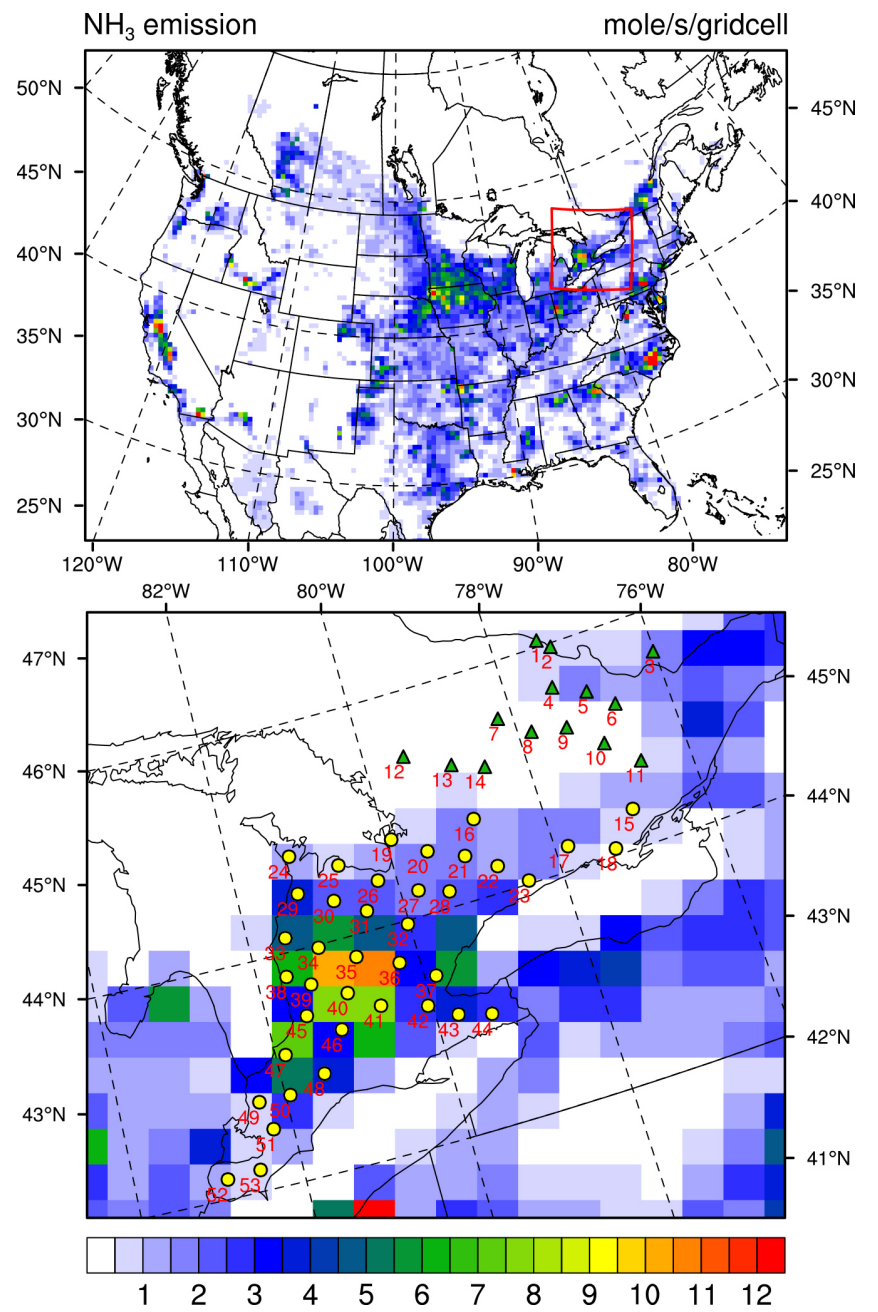

Figure 2. Locations and IDs of 53 measurement sites and spatial distribution of gridded $\mathrm{NH}_{3}$ emissions fluxes (mol s${ }^{-1}$ grid cell ${ }^{-1}$ ) over the simulation domain (top panel) and their local $\mathrm{NH}_{3}$ emission fluxes (the bottom panel is a magnification of the area enclosed by red lines in the top panel). Measurement sites include 14 forest sites (green triangles) and 39 agricultural sites (yellow dots). Note that the emission fluxes are averages over the entire simulation period.

to 30 November 2006. The model was driven by Eta Data Assimilation System (EDAS) data that were obtained from NOAA's Air Resources Laboratory (ARL) meteorological data archives. The EDAS data cover most of North America using $185 \times 129$ grid cells with a horizontal spacing of $40 \mathrm{~km}$. The EDAS data consists of 26 vertical layers with a model top of $25 \mathrm{hPa}$ and are available at 3-hourly intervals. In the model simulations, ensembles of 500 particles were released every hour from each receptor site location at a height of $5 \mathrm{~m}$ above ground. A particle ensemble size of 500 was shown in a previous study (Wen et al., 2013), using the same model and similar inputs, to be sufficient to achieve adequate accuracy while not considerably increasing the computational cost. The paths of the particles were followed backward in time for six days, which usually allowed them to travel far away from any sources near the receptors. The calculated back-trajectories were 3-dimensional and their vertical motions were calculated directly using vertical velocity fields provided in the input meteorological data. The size of the integration time steps for the back-trajectory calculations varied with time and location from $1 \mathrm{~min}$ to $1 \mathrm{~h}$ and was computed based on the requirement that the advection distance per time-step should be less than the grid spacing (CourantFriedrichs-Lewy condition). The same time steps were then also used in the forward simulation for deposition and chemistry calculations.

Identical emissions and initial/boundary conditions to those described in Wen et al. (2013) were employed in this study. A detailed description of the emissions and initial/boundary conditions can be found in Wen et al. (2013), but a brief summary is provided here. Concentrations of modeled species were initialized at the endpoints of trajectories using output from the Model for OZone And Related chemical Tracers, version 4 (MOZART-4) (Emmons et al., 2010), which was obtained from the WRF-Chem website (http://www.acd.ucar.edu/wrf-chem/mozart.shtml). The gridded MOZART- 4 output fields have a $2.8^{\circ} \times 2.8^{\circ}$ horizontal grid spacing with 28 vertical levels from the surface to approximately $2 \mathrm{hPa}$ in 6-hourly intervals. No interpolation of the output was performed for the particle concentration initialization. MOZART-4 chemical species were mapped onto CB4 species according to the matching table given by Emmons et al. (2010). The initial concentrations of particles at trajectory endpoints were then evolved forward in time to account for the influences of emissions, chemical reactions and deposition along each trajectory for each time step in the forward trajectory integrations.

The 2006 Criteria Air Contaminants emission inventory (version 2) from Environment Canada (EC) was employed as the Canadian emission inventory in the simulations, which incorporates facility-level emissions from the EC National Pollutant Release Inventory (i.e., point sources) plus province-level estimates of on-road mobile emissions, off-road mobile emissions, and area emissions (http://www. ec.gc.ca/inrp-npri/). A special inventory of 2006 Canadian agricultural $\mathrm{NH}_{3}$ emissions that was developed under the Canadian National Agri-Environmental Standards Initiative (NAESI) was also included (Makar et al., 2009) to represent regional differences in farming practices and climatic conditions for each livestock category, and temporal variation due to seasonally varying agricultural practices or temperatures. The corresponding US and Mexican emissions inventories that were used were the 2005 US National Emissions Inventory (version 4) and the 1999 Mexican emissions inventory. Both were obtained from the US Environmental Protection Agency (http://www.epa.gov/ttn/chief/ eiinformation.html). These three national anthropogenic inventories all included emissions of oxides of nitrogen $\left(\mathrm{NO}_{\mathrm{x}}\right)$, 
volatile organic compounds (VOC), $\mathrm{NH}_{3}$, carbon monoxide $(\mathrm{CO})$, oxides of sulphur $\left(\mathrm{SO}_{\mathrm{x}}\right)$, and primary particulate matter $(\mathrm{PM})$ with an aerodynamic diameter less than or equal to $10 \mu \mathrm{m}$ and $2.5 \mu \mathrm{m}\left(\mathrm{PM}_{10}\right.$ and $\left.\mathrm{PM}_{2.5}\right)$. Each of the three national emissions inventories was processed with the Sparse Matrix Operator Kernel Emission (SMOKE) (v2.4) (UNC, 2009) emissions processing system for a domain (Fig. 2) that consisted of $150 \times 106$ grid cells with a horizontal grid spacing of $42 \mathrm{~km}$ on a secant-polar-stereographic map projection true at $60^{\circ} \mathrm{N}$. The SMOKE-processed output emissions consisted of hourly gridded emissions fields that accounted for geographic variations and diurnal, weekly and monthly variations. For simplicity all point sources were treated as surface sources, which is reasonable for $\mathrm{NH}_{3}$ emissions because all point sources together account for only a small fraction of total $\mathrm{NH}_{3}$ emission (http://www.ec.gc.ca/inrp-npri/default. asp?lang=en\&n=0EC58C98-1\#Emission_Summaries).

Three dry deposition schemes, including two unidirectional schemes - ZDD and WDD - and the bidirectional scheme ZBE, were used in different STILT-Chem simulations for the 1 June to 30 November 2006 period to investigate their impacts on model predictions of $\mathrm{NH}_{3}$ ambient concentrations. In the ZBE scheme, as mentioned above (Sect. 2.3), two sets of $\Gamma_{\mathrm{st}}$ and $\Gamma_{\mathrm{g}}$ values are available for the same land-use category for forests and grasslands according to canopy nitrogen content. Zhang et al. (2010) suggested that the higher values should be chosen for high-N canopies and the lower values should be chosen for low-N canopies. The classification of high- $\mathrm{N}$ and low-N canopy for each model grid cell can be determined according to a total nitrogen deposition map for the model domain obtained either from measurements or previous mode runs. In this study, due to a lack of such $\mathrm{N}$ deposition maps, we assumed low- $\mathrm{N}$ canopies for all forests and grasslands. This assumption appears to be reasonable because forest areas near the southern Ontario test sites have low $\mathrm{NH}_{3}$ emission strengths and concentrations (cf. Figs. 2 and 3); thus $\mathrm{N}$ deposition in those forest areas should be low because $\mathrm{NH}_{3}$ tends to be a local pollutant. Accordingly, in the STILT-Chem simulation with the ZBE scheme, the minimum emission potential values listed in Table 1 were used and the simulation was treated as a base-case simulation. However, the difference in the modeled $\mathrm{NH}_{3}$ concentrations between simulations by assuming low$\mathrm{N}$ canopies and by assuming high- $\mathrm{N}$ canopies for all forests and grasslands was examined. Some sensitivity simulations were also performed in which larger emission potential values were used for agricultural land-use categories in the ZBE scheme (see Sect. 4.3).
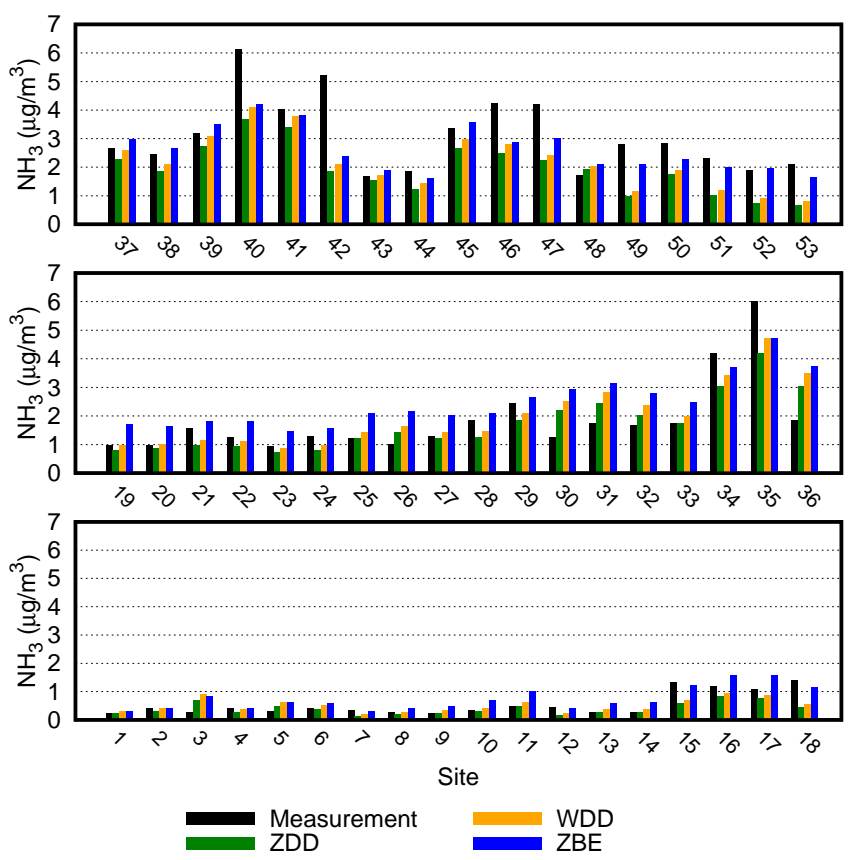

Figure 3. Observed (black) and modeled $\mathrm{NH}_{3}$ concentration averages with the WDD scheme (orange), the ZDD scheme (green), and the ZBE scheme (blue) for 53 measurement sites for the 1 June to 30 November 2006 period. Sites 1 to 14 are forest sites.

\section{Results}

\subsection{Measured and modeled $\mathrm{NH}_{3}$ concentrations using different dry deposition schemes}

Figure 3 shows a site-by-site comparison of average $\mathrm{NH}_{3}$ concentrations between simulations and observations, in which hourly modeled and weekly observed $\mathrm{NH}_{3}$ concentrations were averaged over the entire simulation period from 1 June to 30 November 2006 for each receptor site for the three simulations that used each of the three deposition schemes. Based on the good agreement obtained between simulated and observed values for a similar simulation (Wen et al., 2013), we assumed that the $\mathrm{NH}_{3}$ emission inventory used in this study is reasonable and that the modeled physical and chemical processes (other than dry deposition schemes) do not bias $\mathrm{NH}_{3}$ concentration systematically over the regional scale, so that differences in the modeled $\mathrm{NH}_{3}$ concentration from using the three dry deposition schemes can be compared. Note again that the minimum values of stomatal emission potentials and ground emission potentials given in Table 1 were used in the simulation using the ZBE scheme. We can see from Fig. 3 that the STILT-Chem model using all three schemes generally performed adequately in predicting the average levels of observations for most sites, and also performed well in capturing the general transitional trend in the observations going from forested regions to agricultural regions (see Fig. 2). This is a positive result considering the 

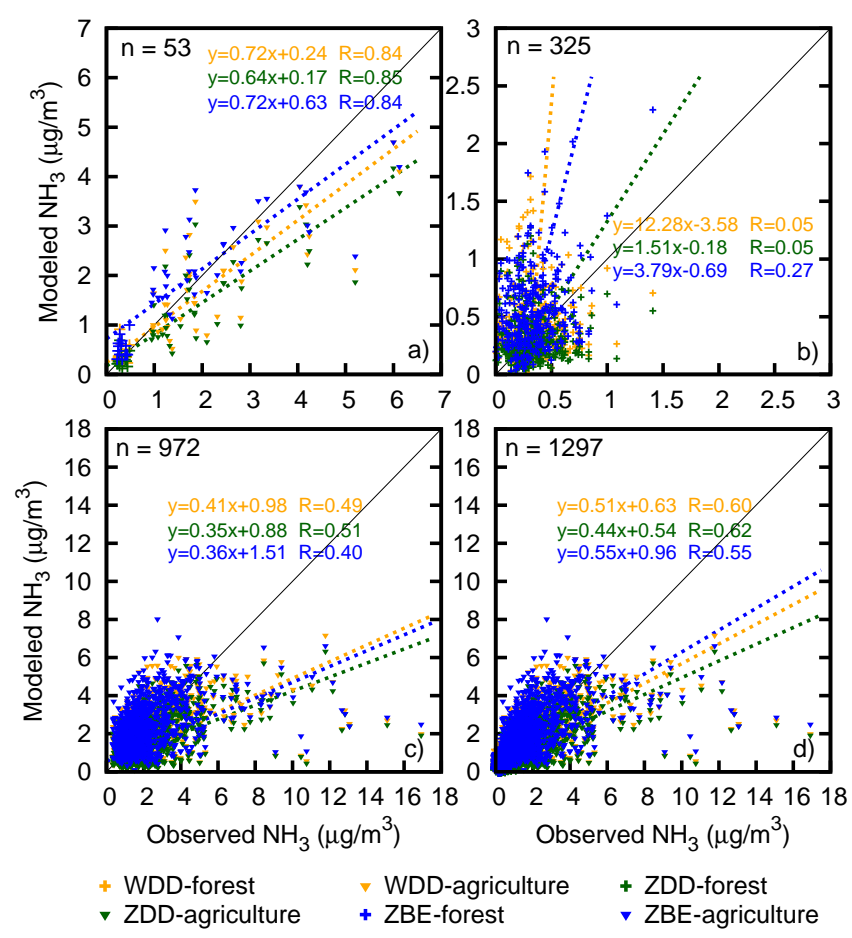

Figure 4. Correlations between measured and modeled $\mathrm{NH}_{3}$ concentrations for the WDD (orange), ZDD (green), and ZDD (blue) schemes, respectively, including: (a) for all 53 sites using mean concentrations over the entire simulation period; (b) for forest sites (+) using weekly concentrations; (c) for agricultural sites ( $\mathbf{\nabla})$ using weekly concentrations; (d) for all 53 sites using weekly concentrations. Solid black lines represents $1: 1$ lines.

fact that $\mathrm{NH}_{3}$ is generally difficult for air quality models to simulate due to its strong spatial variability. Although STILTChem is based on a Lagrangian reference framework and is capable of capturing sub-grid-scale variability (Wen et al., 2011), some processes such as emissions are associated with Eulerian grids in the simulation, and thus the model's performance is still affected by the spatial resolution of input fields. Overall, out of the three schemes, $\mathrm{NH}_{3}$ concentrations predicted using the ZDD scheme were smallest mainly because this scheme generally gives higher $\mathrm{NH}_{3}$ dry deposition velocities (see Sect. 4.2). The highest $\mathrm{NH}_{3}$ concentrations were predicted by the ZBE scheme due mainly to the inclusion of additional $\mathrm{NH}_{3}$ emissions from ground and canopy vegetation.

Figure 4a shows correlations between observed and modeled mean $\mathrm{NH}_{3}$ concentrations that are presented in Fig. 3 for the three schemes. The ZBE scheme generally predicted higher $\mathrm{NH}_{3}$ concentration averages over the entire simulation period than the ZDD and WDD schemes. However, all three schemes produced almost equivalent correlation patterns with the observations. They underestimated $\mathrm{NH}_{3}$ concentrations at sites with high observed concentrations, while overestimating $\mathrm{NH}_{3}$ concentrations at sites with low
Table 2. Definition of statistical metrics.

\begin{tabular}{lc}
\hline Parameter & Definition \\
\hline Ratio of the Means (ROM) & $\left(\frac{1}{N} \sum_{i=1}^{N} P_{i}\right) /\left(\frac{1}{N} \sum_{i=1}^{N} O_{i}\right)$ \\
Mean Fractional Bias (MFB) & $\frac{1}{N} \sum_{i=1}^{N} \frac{P_{i}-O_{i}}{\left(P_{i}+O_{i}\right) / 2} \times 100 \%$ \\
Mean Fractional Error (MFE) & $\frac{1}{N} \sum_{i=1}^{N} \frac{\left|P_{i}-O_{i}\right|}{\left(P_{i}+O_{i}\right) / 2} \times 100 \%$ \\
\hline
\end{tabular}

$P_{i}$ : prediction at time $i ; O_{i}$ : observation at time $i ; N$ : total number of observations or predictions.

observed concentrations. This phenomenon is more evident in the scatter plots (Fig. 4b, c, and d) in which weekly measured and modeled concentrations were used. Similar results have been reported by a European study that used the LOng Term Ozone Simulation - EURopean Operational Smog (LOTOS-EUROS) model (Wichink Kruit et al., 2012), in which $\mathrm{NH}_{3}$ concentrations in natural areas were slightly overestimated, whereas $\mathrm{NH}_{3}$ concentrations in agricultural regions were underestimated, with more pronounced underestimations as observed $\mathrm{NH}_{3}$ levels increased. In terms of statistical values of the Ratio of the Means (ROM) and the Mean Fractional Bias (MFB) (Tables 2 and 3), modeled $\mathrm{NH}_{3}$ concentrations at agricultural sites were overall underestimated by WDD and ZDD in this study, and slightly overestimated by ZBE, but all three schemes significantly underestimated $\mathrm{NH}_{3}$ concentrations for sites with observed levels greater than $6.0 \mu \mathrm{g} \mathrm{m}^{-3}$, with a tendency to underestimate more with increasing observed concentrations (Fig. 4). The performances of the three schemes at agricultural sites were not obviously different according to their correlations with observations but differed significantly from the perspective of bias (Fig. 4 and Table 3). All three schemes performed poorly in reproducing observed concentrations at the forest sites, with considerable overestimation and ineffective representation of the pattern of observations, probably due to much lower emissions strengths and concentration levels at those sites. The same uncertainty in the simulations may lead to more pronounced error/bias at low concentrations than high concentrations. According to the values of ROM, MFB and Mean Fractional Error (MFE) in Table 3, the ZBE scheme performed the best for agricultural sites and for all sites, whereas the ZDD scheme had the best performance in simulating $\mathrm{NH}_{3}$ concentrations for the forested sites.

Figure 5 shows time series of observed and simulated $\mathrm{NH}_{3}$ concentrations, in which modeled hourly $\mathrm{NH}_{3}$ concentrations were averaged according to corresponding weekly sampling periods, and then observed and modeled weekly concentrations were averaged over receptor sites for three groups: forest sites, agricultural sites, and all sites. All three schemes generally performed well in capturing the timing of 
Table 3. Values of three statistical metrics for comparison of weekly modeled $\mathrm{NH}_{3}$ concentrations against observations for the $1 \mathrm{June}$ to 30 November 2006 period for three groups of sites: (1) all sites (53); (2) forested sites (14); (3) agricultural sites (39).

\begin{tabular}{|c|c|c|c|c|c|c|c|c|c|}
\hline \multirow[t]{2}{*}{ Metrics } & \multicolumn{3}{|c|}{ All sites } & \multicolumn{3}{|c|}{ Agricultural sites } & \multicolumn{3}{|c|}{ Forested sites } \\
\hline & WDD & ZDD & ZBE & WDD & ZDD & ZBE & WDD & ZDD & ZBE \\
\hline ROM & 0.85 & 0.74 & 1.07 & 0.83 & 0.73 & 1.04 & 1.27 & 0.95 & 1.68 \\
\hline MFB (\%) & -2.40 & -24.18 & 23.40 & -14.15 & -26.48 & 12.72 & 32.77 & -17.30 & 55.32 \\
\hline $\operatorname{MFE}(\%)$ & 56.65 & 52.25 & 57.73 & 48.04 & 50.10 & 49.38 & 82.37 & 58.66 & 82.72 \\
\hline
\end{tabular}

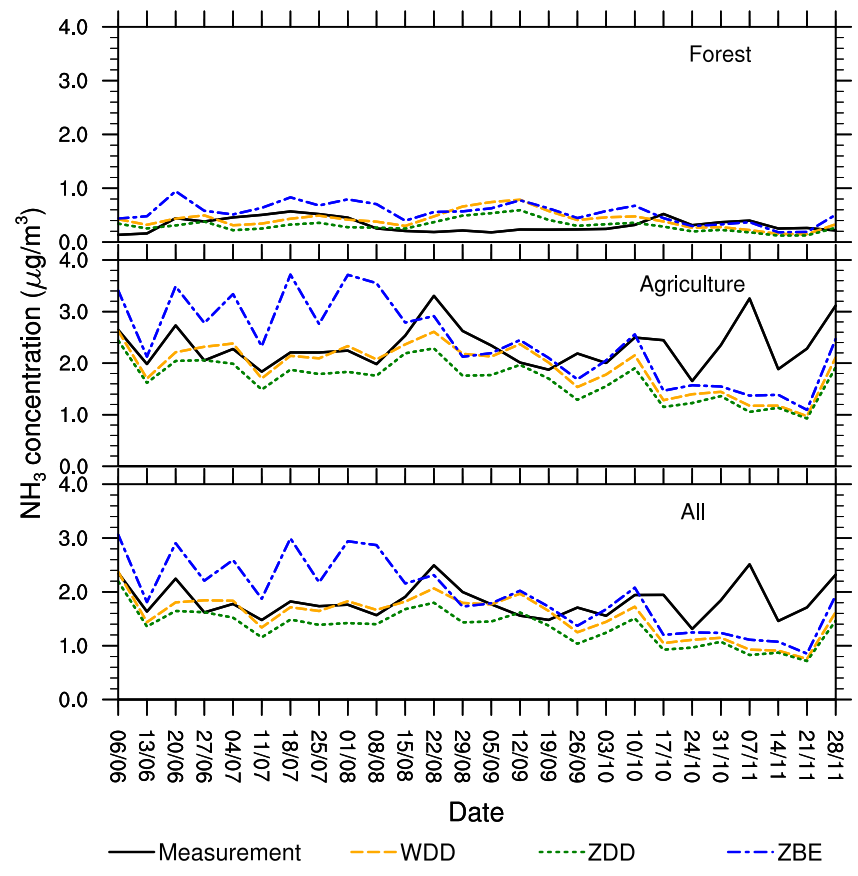

Figure 5. Observed $\mathrm{NH}_{3}$ concentration time series (black continuous line) vs. modeled time series using the WDD scheme (orange), the ZDD scheme (green), and the ZBE scheme (blue), respectively. Those time series are averages over forest sites (top), agricultural sites (middle), and all 53 sites (bottom).

peaks in the observations, albeit the exact predicted concentration levels were different. From statistics calculated using values of the mean time series displayed in Fig. 5, the ZDD scheme performed best in capturing average levels of observation for forest sites, with a ROM of 0.95 , compared with 1.27 for WDD and 1.68 for ZBE, respectively. The ZBE scheme, on the other hand, performed best in capturing average levels for both agricultural sites and all sites. For agricultural sites ZBE had a ROM of 1.04, compared 0.73 for ZDD and 0.83 for WDD, and for all sites the ZBE scheme had a ROM of 1.07, compared with 0.74 for ZDD and 0.85 for WDD. All three schemes had relatively poor correlations with observations for all three groups of sites, with a maximum value of 0.48 . The ZBE scheme substantially overestimated $\mathrm{NH}_{3}$ concentrations over forest sites and the ZDD scheme clearly underestimated $\mathrm{NH}_{3}$ concentrations over agricultural sites. Their performances also varied for different simulation periods. Before mid-October, both WDD and ZDD can predict $\mathrm{NH}_{3}$ concentrations well, indicating that the anthropogenic $\mathrm{NH}_{3}$ emissions used for this period of time were reasonable. After mid-October, however, there was a universal sharp decrease in modeled $\mathrm{NH}_{3}$ concentrations (especially at agricultural sites), mainly in response to a reduction of the estimated $\mathrm{NH}_{3}$ emissions as a result of lower emissions of $\mathrm{NH}_{3}$ from livestock production and fertilizer application in southern Ontario in the winter months (Lillyman et al., 2010), as well as by the presence of snow cover, which typically begins in November in southern Ontario and which can substantially reduce $\mathrm{NH}_{3}$ soil emissions. However, the big difference between modeled and observed $\mathrm{NH}_{3}$ concentrations for all three schemes after mid-October may suggest a significant underestimation of anthropogenic $\mathrm{NH}_{3}$ emissions after mid-October, presumably as a result of neglecting likely fertilizer application from October to November in preparation for the following year's agricultural activity. As for the period before mid-August, the two unidirectional schemes predicted $\mathrm{NH}_{3}$ well whereas ZBE clearly overestimated. The overestimation of ZBE was probably due to the use of constant stomatal emission potentials for the entire modeling period, which are likely too high for this period of time. By contrast the modeled results by ZBE agree well with the observations at the forest sites after mid-October and at the agricultural sites from mid-August to mid-October. Since temperature generally decreases after mid-August and $\mathrm{NH}_{3}$ concentrations overall were overestimated before midAugust, the good agreement later on could be a result of lower temperatures as stomatal and ground compensation points decrease exponentially with decreasing temperature (Eqs. 7 and 9).

\subsection{Modeled dry deposition velocity and flux using different schemes}

Hourly modeled results for the entire simulation period were used to calculate average diurnal variations of $\mathrm{NH}_{3}$ concentration, dry deposition velocity and air-surface exchange flux. The resulting average diurnal variations in these three quantities for the three schemes are presented in Fig. 6 for the forest sites and the agricultural sites. Figure 6 shows that the dry deposition velocities of $\mathrm{NH}_{3}$ modeled by the WDD 


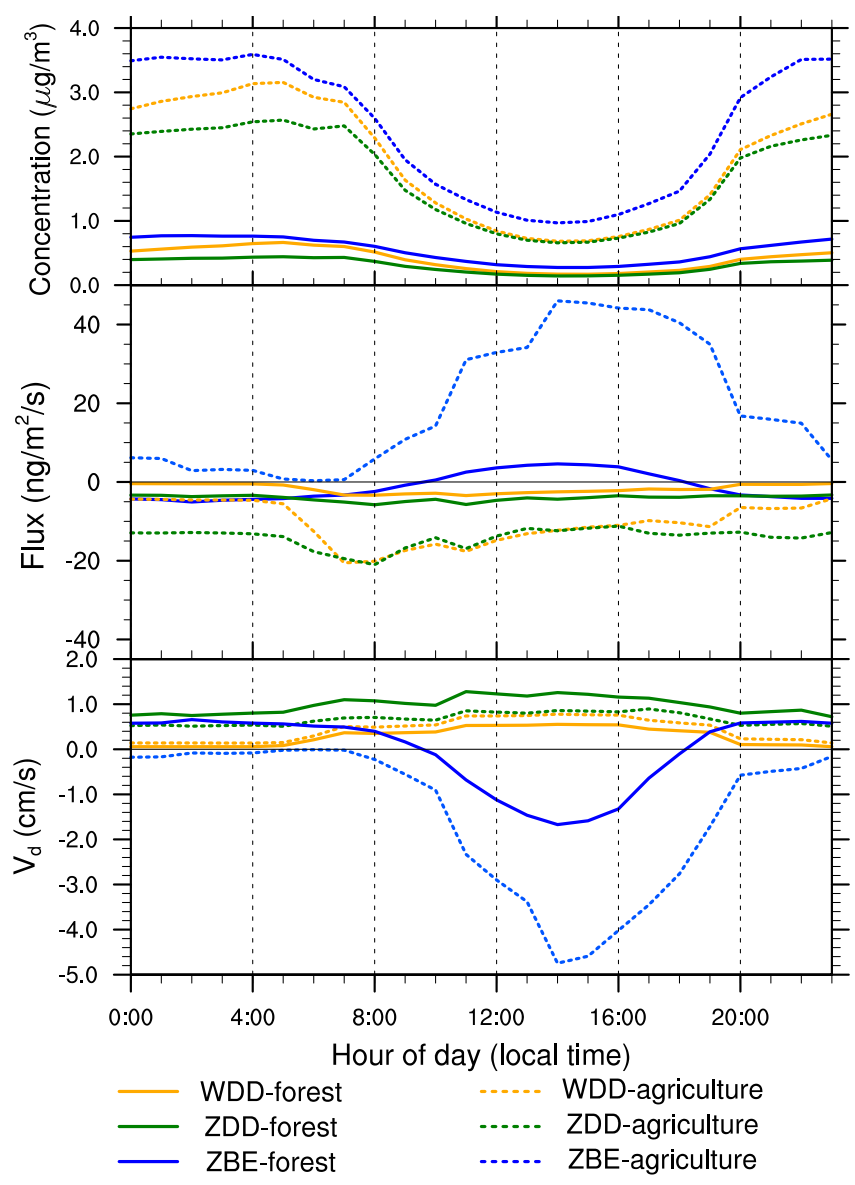

Figure 6. Diurnal variations of modeled dry deposition velocity (bottom), surface exchange flux (middle), and $\mathrm{NH}_{3}$ concentration (top) using WDD (orange), ZDD (green), and ZBE (blue) schemes, respectively, averaged over the entire simulation period for forest sites (solid lines) and agricultural sites (dashed lines). Negative fluxes represent downward movement out of the atmosphere whereas positive fluxes represent emissions from the Earth's surface to the atmosphere. Dry deposition velocities for ZBE represent its effective dry deposition velocities, where negative values indicate emissions from surface.

scheme were smaller than those modeled by the ZDD scheme for the agricultural and especially for the forest sites. The underestimation of dry deposition velocities by the WDD scheme has been reported by other studies (Wu et al., 2012) and was attributed to the use of a prescribed minimum nonstomatal resistance without consideration of key biological factors (e.g., LAI). In contrast, the non-stomatal resistance parameterizations adopted in the ZDD scheme vary with biological (LAI), meteorological (friction velocity, relative humidity), and surface (canopy wetness) conditions, and therefore are better able to capture the variations of dry deposition velocity than the simple non-stomatal resistance parameterization in the WDD scheme. The $\mathrm{NH}_{3}$ dry deposition velocity estimated by WDD for forest sites was even smaller than that for the agricultural sites, mainly due to the exclusion of stomatal uptake (through the use of a very large value of $10^{25} \mathrm{~s} \mathrm{~m}^{-1}$ for minimum canopy stomatal resistance) for the deciduous forest category in the autumn season. In WDD, September-October is treated as autumn and foliage loss is thus assumed. The underprediction of dry deposition velocities of $\mathrm{O}_{3}$ by the WDD scheme for September-October has also been previously reported (Wu et al., 2011). The ZBE scheme, on the other hand, calculated $\mathrm{NH}_{3}$ flux directly and no $\mathrm{NH}_{3}$ dry deposition velocity was estimated in the ZBE scheme. In order to compare it with the other schemes, we divided $\mathrm{NH}_{3}$ fluxes by corresponding $\mathrm{NH}_{3}$ concentrations to obtain an "effective" dry deposition velocity for the ZBE scheme. Hence diurnal patterns of effective dry deposition velocities for the ZBE scheme are presented in Fig. 6 as well. The effective dry deposition velocities from the ZBE scheme clearly show strong $\mathrm{NH}_{3}$ emission (negative values) from the surface to the atmosphere during the daytime for both forest and agricultural sites. During the nighttime, ZBE effective deposition velocities are close to the dry deposition velocities estimated by ZDD for forest sites, but they are small and negative for agricultural sites.

Modeled $\mathrm{NH}_{3}$ fluxes using ZDD and WDD show evident diurnal patterns in which magnitude of fluxes were smaller at night and larger during daytime hours. All fluxes were negative (downward out of the atmosphere) due to consideration solely of dry deposition in those unidirectional schemes. Although modeled $\mathrm{NH}_{3}$ dry deposition velocities by $\mathrm{ZDD}$ were larger for forest sites than for agricultural sites, $\mathrm{NH}_{3}$ fluxes modeled by both WDD and ZDD were higher for agricultural sites than for forest sites. The main reason is that dry deposition flux is determined not only by dry deposition velocity but also by ambient concentration, and $\mathrm{NH}_{3}$ concentrations at the agricultural sites were much higher than those at the forest sites as shown in the top panel of Fig. 6. Downward fluxes predicted by ZDD were greater than those predicted by WDD for both forest and agricultural sites: as a consequence, modeled $\mathrm{NH}_{3}$ concentrations based on ZDD were generally smaller than those based on WDD (see also Figs. 3 and 5).

Unlike the diurnal patterns of $\mathrm{NH}_{3}$ surface fluxes predicted by the unidirectional schemes, in which all fluxes were downward (negative), the $\mathrm{NH}_{3}$ surface fluxes predicted by the ZBE scheme were mostly upward (positive), especially for the agricultural sites where almost all fluxes were positive and had a much higher peak. Estimated fluxes over the forest sites were negative at night (Fig. 6) but reached maximum (positive) values in the afternoon. Flux peaks for both the agricultural sites and the forest sites are coincident with the ambient concentration minima as expected from Eq. (5). The mean flux of the diurnal pattern was about $-1.2 \mathrm{ng} \mathrm{m}^{-2} \mathrm{~s}^{-1}$ for the forest sites, and $19.2 \mathrm{ng} \mathrm{m}^{-2} \mathrm{~s}^{-1}$ for the agricultural sites, indicating that $\mathrm{NH}_{3}$ air-surface exchange at the agricultural sites acted as an important source of $\mathrm{NH}_{3}$ to the atmosphere during the study period, based on the ZBE results. 

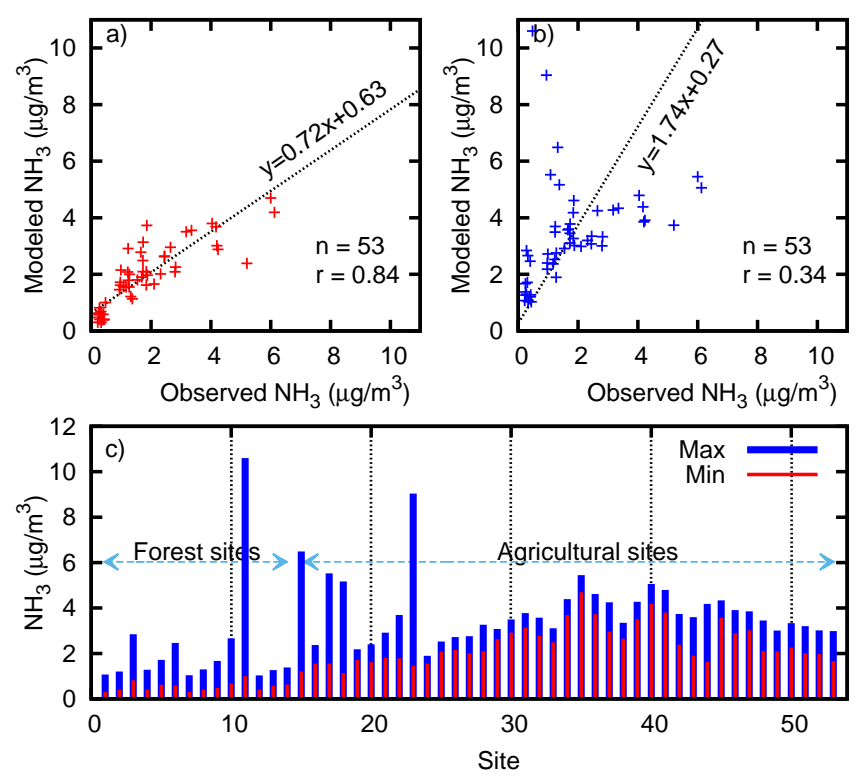

Figure 7. Modeled average $\mathrm{NH}_{3}$ concentration (c) using the set of minimum emission potentials (red) and using the set of maximum emission potentials (blue) for 53 measurement sites and their correlations with the observations ( $\mathbf{a}$ and $\mathbf{b}$ ). The use of minimum emission potentials is the default.

\subsection{Uncertainty associated with emission potentials in the ZBE scheme}

As discussed in Sect. 2.3, two parameters are required to determine air-surface exchange of $\mathrm{NH}_{3}$ : stomatal emission potential $\left(\Gamma_{\mathrm{st}}\right)$ and soil emission potential $\left(\Gamma_{\mathrm{g}}\right)$. Although these parameters can be measured at selected locations, they are not available at regional scales nor are they calculated in regional-scale air quality models. For regional-scale air quality modeling applications, the ZBE scheme employs $\Gamma_{\text {st }}$ and $\Gamma_{\mathrm{g}}$ values that have been derived empirically for each landuse category. Two empirical sets of $\Gamma_{\mathrm{st}}$ and $\Gamma_{\mathrm{g}}$ values were provided (Table 1) to reflect different nitrogen contents for the same land-use category that forests and grasslands might have. Thus the use of different empirical emission potential values could lead to different simulation results.

In order to bracket uncertainties in modeled $\mathrm{NH}_{3}$ concentrations associated with the use of the different emissionpotential values, we ran the model twice - once using the minimum and again using the maximum emission potentials given in Table 1 - with the ZBE scheme for every location in the simulation domain. Note that for some land-use categories (e.g., crops) the same emission potential was used for both runs due to only one value being available. Modeled $\mathrm{NH}_{3}$ concentrations were then averaged over the entire simulation period for each test site, and the average concentrations for the two runs are presented in Fig. 7 for comparison. Figure 7 shows that differences in modeled $\mathrm{NH}_{3}$ concentrations from using the maximum and minimum emission potentials

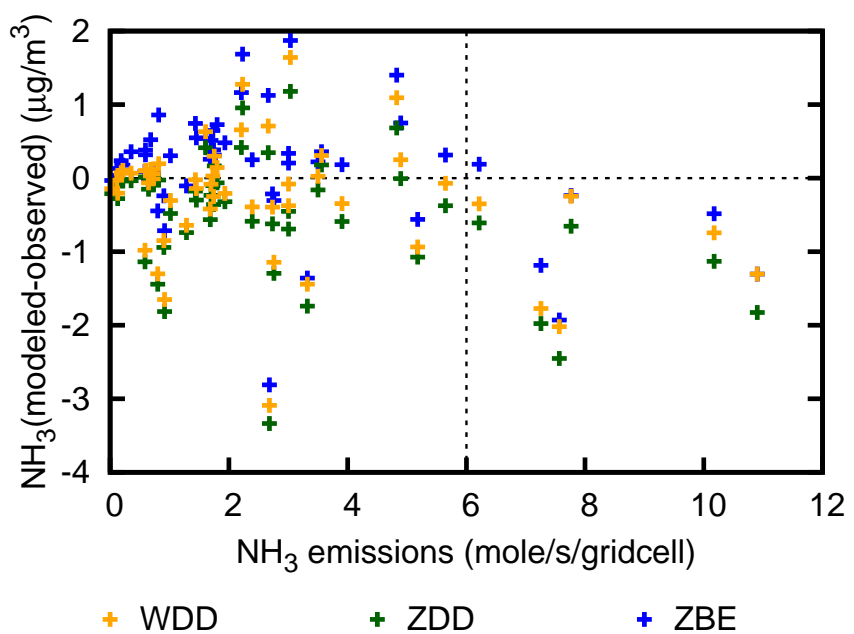

Figure 8. Scatterplot for deviations of modeled $\mathrm{NH}_{3}$ concentrations from observed values vs. corresponding mean anthropogenic emission strengths for the three schemes for each test sites. All data points are means for the entire simulation period.

were marked, especially for most forest sites. Using maximum emission potentials not only greatly overestimated $\mathrm{NH}_{3}$ concentrations, but also significantly reduced the correlation between simulation and observations. The mean $\mathrm{NH}_{3}$ concentration for the forest sites was $2.25 \mu \mathrm{g} \mathrm{m}^{-3}$ when maximum emission potentials were used, about 4 times the mean value of $0.54 \mu \mathrm{g} \mathrm{m}^{-3}$ obtained when the minimum emission potentials were used. This result indicates the importance of using appropriate emission potentials in $\mathrm{NH}_{3}$ bidirectional modeling. Although the same emission potential values were used for both runs for agricultural locations (agriculture related land-use categories only had one emission-potential value: see Table 1), differences in modeled concentrations for those locations were still evident. The mean $\mathrm{NH}_{3}$ concentration for agricultural sites was $3.81 \mu \mathrm{g} \mathrm{m}^{-3}$ when maximum emission potentials were used and approximately 1.5 times the mean concentration of $2.42 \mu \mathrm{g} \mathrm{m}^{-3}$ obtained using minimum emission potentials. This difference resulted from the transport of higher $\mathrm{NH}_{3}$ concentrations from forest areas when maximum emission potentials were used.

Figure 8 shows relationships between deviations of modeled $\mathrm{NH}_{3}$ concentrations from observations and corresponding local mean anthropogenic $\mathrm{NH}_{3}$ emissions for each site (see Fig. 2). All data points in Fig. 8 are means over the entire simulation period for the 53 sites for all three schemes. Those for the ZBE scheme were the outcome of using minimum emission potentials. The deviations of modeled $\mathrm{NH}_{3}$ concentrations from observed values clearly show a negative correlation with anthropogenic $\mathrm{NH}_{3}$ emissions, which is more obvious for ZBE than for the other schemes. When anthropogenic emissions strength was greater than 6.0 mole s$^{-1}$ gridcell $^{-1}$, all three schemes underestimated $\mathrm{NH}_{3}$ concentrations. Even for the $\mathrm{ZBE}$ scheme, 
Table 4. Selected statistics for emission-potential sensitivity tests with the ZBE scheme for five measurement sites with strong anthropogenic $\mathrm{NH}_{3}$ emissions. PEP are the pre-defined emission-potential values in Table 1 for land-use categories related to agriculture.

\begin{tabular}{lccc}
\hline $\begin{array}{l}\text { Tested emission } \\
\text { potentials }\end{array}$ & ROM & $\begin{array}{c}\text { MFB } \\
(\%)\end{array}$ & $\begin{array}{c}\text { MFE } \\
(\%)\end{array}$ \\
\hline $1 \times$ PEP & 0.79 & -22.59 & 22.59 \\
$2 \times$ PEP & 0.88 & -13.56 & 14.43 \\
$3 \times$ PEP & 0.99 & -2.13 & 11.11 \\
$4 \times$ PEP & 1.09 & 8.15 & 11.31 \\
$6 \times$ PEP & 1.31 & 25.87 & 25.87 \\
\hline
\end{tabular}

which generally predicts the highest concentrations among the schemes, the underestimation can still be significant. The underestimation of $\mathrm{NH}_{3}$ concentrations indicates that emission potentials specified in the ZBE scheme (Table 1) might be not large enough for those highly polluted sites.

In order to quantify how much emission potentials might potentially be underestimated, we conducted several sensitivity tests using different emission potentials for all locations where mean anthropogenic $\mathrm{NH}_{3}$ emissions exceeded 6.0 mole s $^{-1}$ gridcell $^{-1}$. Out of 53 sites, there were five agricultural sites that satisfied this condition. Those five sites were selected as test sites in this sensitivity study. The values of emission potentials tested were 2, 3, 4, and 6 times the magnitudes of the pre-defined values in Table 1 for land-use categories related to agriculture (categories 15 to 20 in Table 1). Note that those categories only have one emission-potential value for each category. Modeled mean $\mathrm{NH}_{3}$ concentrations over the entire simulation period were compared for these tests with observations and results are summarized in Table 4. Examination of Table 4 suggests that there is a strong sensitivity to the choice of emission potential value. It further suggests that the pre-defined values of the emission potentials used in the ZBE scheme might be substantially underestimated for sites with strong anthropogenic $\mathrm{NH}_{3}$ emissions. According to these tests, values of emission potentials at least three times larger than those specified in Table 1 are required in order to reasonably predict $\mathrm{NH}_{3}$ concentrations at sites with anthropogenic emission strengths greater than 6.0 mole $\mathrm{s}^{-1}$ gridcell $^{-1}$.

\section{Summary and conclusions}

An air-surface bidirectional exchange scheme developed for regional $\mathrm{NH}_{3}$ modeling was incorporated in the STILT-Chem v0.8 air quality model for this study. STILT-Chem v0.8 was then applied to simulate $\mathrm{NH}_{3}$ concentrations at 53 measurement sites in southern Ontario for a simulation period from 1 June to 30 November 2006, using the bidirectional scheme (ZBE) and two unidirectional dry deposition schemes (WDD and ZDD). Modeled $\mathrm{NH}_{3}$ concentrations obtained using these three schemes were compared against weekly passivesampler $\mathrm{NH}_{3}$ measurements for each site. The comparisons indicate that in general all three schemes can reproduce the observed $\mathrm{NH}_{3}$ concentrations reasonably well. However, the three schemes performed differently at locations with different $\mathrm{NH}_{3}$ concentration levels. Modeled results show that the bidirectional scheme performed best at locations with high observed $\mathrm{NH}_{3}$ concentrations but overestimated $\mathrm{NH}_{3}$ levels for locations with low observed $\mathrm{NH}_{3}$ concentrations. The two unidirectional dry deposition schemes, on the other hand, generally performed better than the bidirectional scheme at sites with low observed $\mathrm{NH}_{3}$ concentrations.

The absolute or relative errors in the modeled $\mathrm{NH}_{3}$ concentrations obtained using the three different dry deposition schemes were examined and interpreted based on the assumption that other processes did not cause any systematic biases. One possible systematic bias, however, could be caused by the underestimation of $\mathrm{NH}_{3}$ emissions, as emissions data for biogeochemical sources like biogenic $\mathrm{N}$ fixation in agricultural systems and/or atmospheric deposition of $\mathrm{NO}_{\mathrm{y}}$ followed by soil $\mathrm{N}$ cycling processes (e.g., Beusen et al., 2008; Galloway et al., 2008) are generally not available and hence are not included in available $\mathrm{NH}_{3}$ emissions inventories. The omission of such emissions could lead to underestimation of atmospheric $\mathrm{NH}_{3}$ concentrations. Though the appropriateness of this assumption could not be verified directly in this study, the good agreement between model simulations and observations suggests that systematic biases in the simulations are small. Moreover, the absolute or relative errors caused by those systematic biases might be shifted to one direction only because the same model and input data were used for all three dry deposition schemes.

If stomatal and ground emission potentials were set to zero in the ZBE scheme, the ZBE scheme and the ZDD scheme would yield the same $\mathrm{NH}_{3}$ flux. The reason is that the ZBE scheme was developed from the ZDD scheme and both schemes uses the same formulas to compute the dry deposition component (Zhang et al., 2010). In other words, the ZDD scheme acts as a special case of the $\mathrm{ZBE}$ scheme in $\mathrm{NH}_{3}$ bidirectional exchange modeling. Since the ZDD scheme more accurately predicted $\mathrm{NH}_{3}$ concentrations at locations with low $\mathrm{NH}_{3}$ concentrations than the ZBE scheme (Fig. 4), the appropriateness of the application of the current version of the bidirectional scheme to low $\mathrm{NH}_{3}$ concentration locations needs reconsideration and further investigation. Uncertainties in the magnitudes of the emission-potential values used for both low- $\mathrm{NH}_{3}$ and high- $\mathrm{NH}_{3}$ concentration locations also require more research.

\section{Code availability}

STILT-Chem v0.8 is written in Fortran. Model runs are controlled by a shell script. A brief manual is included in the model package. The STILT-Chem v0.8 model code will be 
available online for free access in the near future. For the time being, the model can be obtained by contacting John C. Lin (john.lin@utah.edu).

Acknowledgements. We gratefully acknowledge funding from Environment Canada for supporting D. Wen and the important contribution of G. Beaney of Environment Canada in making the SOAPSS ammonia measurements. We also thank Q. Zheng and J. Zhang of Environment Canada for preparing the emissions files used in this study. This work was made possible by the facilities of the Shared Hierarchical Academic Research Computing Network (SHARCNET: http://www.sharcnet.ca) and Compute/Calcul Canada.

Edited by: V. Grewe

\section{References}

Alexander, B., Park, R. J., Jacob, D. J., Li, Q. B., Yantosca, R. M., Savarino, J., Lee, C. C. W., and Thiemens, M. H.: Sulfate formation in sea-salt aerosols: constraints from oxygen isotopes, J. Geophys. Res., 110, D10307, doi:10.1029/2004JD005659, 2005.

Bash, J. O., Cooter, E. J., Dennis, R. L., Walker, J. T., and Pleim, J. E.: Evaluation of a regional air-quality model with bidirectional $\mathrm{NH}_{3}$ exchange coupled to an agroecosystem model, Biogeosciences, 10, 1635-1645, doi:10.5194/bg-10-1635-2013, 2013

Beusen, A., Bouwman, A. F., Heuberger, P., Van Drecht, G., and Van Der Hoek, K. W.: Bottomup uncertainty estimates of global ammonia emissions from global agricultural production systems, Atmos. Environ., 42, 6067-6077, doi:10.1016/j.atmosenv.2008.03.044, 2008.

Chang, J. S.: NAPAP Report 4, the regional acid deposition model and engineering model, Appendix E, in: Acid Deposition: State of Science and Technology, vol I, Emissions, Atmospheric Processes, and Deposition, US Government Printing Office, Washington, DC, 20402-9325, 1990.

Cooter, E. J., Bash, J. O., Walker, J. T., Jones, M. R., and Robarge, W.: Estimation of $\mathrm{NH}_{3}$ bi-directional flux from managed agricultural soils, Atmos. Environ., 44, 2107-2115, doi:10.1016/j.atmosenv.2010.02.044, 2010.

Cooter, E. J., Bash, J. O., Benson, V., and Ran, L.: Linking agricultural crop management and air quality models for regional to national-scale nitrogen assessments, Biogeosciences, 9, 40234035, doi:10.5194/bg-9-4023-2012, 2012.

Draxler, R. R. and Hess, G. D.: Description of the HYSPLIT 4 Modeling System, NOAA Technical Memorandum ERL ARL-224, 1997.

Emmons, L. K., Walters, S., Hess, P. G., Lamarque, J.-F., Pfister, G. G., Fillmore, D., Granier, C., Guenther, A., Kinnison, D., Laepple, T., Orlando, J., Tie, X., Tyndall, G., Wiedinmyer, C., Baughcum, S. L., and Kloster, S.: Description and evaluation of the Model for Ozone and Related chemical Tracers, version 4 (MOZART-4), Geosci. Model Dev., 3, 43-67, doi:10.5194/gmd3-43-2010, 2010.

Flechard, C. R., Massad, R.-S., Loubet, B., Personne, E., Simpson, D., Bash, J. O., Cooter, E. J., Nemitz, E., and Sutton, M. A.: Advances in understanding, models and parameterizations of biosphere-atmosphere ammonia exchange, Biogeosciences, 10, 5183-5225, doi:10.5194/bg-10-5183-2013, 2013.

Galloway, J. N., Townsend, A. R., Erisman, J. W., Bekunda, M., Cai, Z., Freney, J. R., Martinelli, L. A., Seitzinger, S. P., and Sutton, M. A.: Transformation of the nitrogen cycle: recent trends, questions, and potential solutions, Science, 320, 889-892, doi:10.1126/science.1136674, 2008.

Geels, C., Andersen, H. V., Ambelas Skjøth, C., Christensen, J. H., Ellermann, T., Løfstrøm, P., Gyldenkærne, S., Brandt, J., Hansen, K. M., Frohn, L. M., and Hertel, O.: Improved modelling of atmospheric ammonia over Denmark using the coupled modelling system DAMOS, Biogeosciences, 9, 2625-2647, doi:10.5194/bg-9-2625-2012, 2012.

Gery, M. W., Whitten, G. Z., Killus, J. P., and Dodge, M. C.: A photochemical kinetics mechanism for urban and regional scale computer modeling, J. Geophys. Res., 94, 12925-12956, doi:10.1029/JD094iD10p12925, 1989.

Lillyman, C., Buset, K., and Mullins, D.: 2008 Canadian Atmospheric Assessment of Agricultural Ammonia, National AgriEnvironmental Standards, Environment Canada, Gatineau, Que, ISBN 9781100124209, 295 pp., 2010.

Lin, J. C., Gerbig, C., Wofsy, S. C., Andrews, A. E., Daube, B. C., Davis, K. J., and Grainger, C. A.: A near-field tool for simulating the upstream influence of atmospheric observations: the Stochastic Time-inverted Lagrangian Transport (STILT) model, J. Geophys. Res., 108, 4493, doi:10.1029/2002JD003161, 2003.

Makar, P. A., Moran, M. D., Zheng, Q., Cousineau, S., Sassi, M., Duhamel, A., Besner, M., Davignon, D., Crevier, L.-P., and Bouchet, V. S.: Modelling the impacts of ammonia emissions reductions on North American air quality, Atmos. Chem. Phys., 9 , 7183-7212, doi:10.5194/acp-9-7183-2009, 2009.

Morris, J. T.: Effects of nitrogen loading on wetland ecosystems with particular reference to atmospheric deposition, Annu. Rev. Ecol. Syst., 22, 257-279, doi:10.1146/annurev.es.22.110191.001353, 1991.

Nemitz, E., Sutton, M. A., Schjoerring, J. K., Husted, S., and Wyers, G. P.: Resistance modelling of ammonia exchange over oilseed rape, Agr. Forest Meteorol., 105, 405-425, doi:10.1016/S0168-1923(00)00206-9, 2000.

Nemitz, E., Milford, C., and Sutton, M. A.: A two-layer canopy compensation point model for describing bi-directional biosphere-atmosphere exchange of ammonia, Q. J. Roy. Meteor. Soc., 127, 815-833, doi:10.1002/qj.49712757306, 2001.

Nemitz, E., Sutton, M. A., Wyers, G. P., and Jongejan, P. A. C.: Gas-particle interactions above a Dutch heathland: I. Surface exchange fluxes of $\mathrm{NH}_{3}, \mathrm{SO}_{2}, \mathrm{HNO}_{3}$ and $\mathrm{HCl}$, Atmos. Chem. Phys., 4, 989-1005, doi:10.5194/acp-4-989-2004, 2004.

Nopmongcol, U., Koo, B., Tai, E., Jung, J., Piyachaturawat, P., Emery, C., Yarwood, G., Pirovano, G., Mitsakou, C., and Kallos, G.: Modeling Europe with CAMx for the Air Quality Model Evaluation International Initiative (AQMEII), Atmos. Environ., 53, 177-185, doi:10.1016/j.atmosenv.2011.11.023, 2012.

Pleim, J. E., Bash, J. O., Walker, J. T., and Cooter, E. J.: Development and evaluation of an ammonia bi-directional flux parametrization for air quality models, J. Geophys. Res.-Atmos., 118, 3794-3806, doi:10.1002/jgrd.50262, 2013.

Pope, C. A., Ezzati, M., and Dockery, D. W.: Fine-particulate air pollution and life expectancy in the US, New Engl. J. Med., 360, 376-386, doi:10.1056/NEJMsa0805646, 2009. 
Seinfeld, J. H. and Pandis, S. N.: Atmospheric Chemistry and Physics: From Air Pollution to Climate Change, 2nd Edn., J. Wiley, New York, 2006.

Simpson, D., Benedictow, A., Berge, H., Bergström, R., Emberson, L. D., Fagerli, H., Flechard, C. R., Hayman, G. D., Gauss, M., Jonson, J. E., Jenkin, M. E., Nyíri, A., Richter, C., Semeena, V. S., Tsyro, S., Tuovinen, J.-P., Valdebenito, Á., and Wind, P.: The EMEP MSC-W chemical transport model - technical description, Atmos. Chem. Phys., 12, 7825-7865, doi:10.5194/acp-12-7825-2012, 2012.

Slinn, S. A. and Slinn, W. G. N.: Predictions for particle deposition on natural waters, Atmos. Environ., 14, 1013-1016, doi:10.1016/0004-6981(80)90032-3, 1980.

Sutton, M. A., Burkhardt, J. K., Guerin, D., Nemitz, E., and Fowler, D.: Development of resistance models to describe measurements of bi-directional ammonia surface-atmosphere exchange, Atmos. Environ., 32, 473-480, doi:10.1016/S13522310(97)00164-7, 1998.

Taylor, K. E.: Summarizing multiple aspects of model performance in a single diagram, J. Geophys. Res., 106, 7183-7192, doi:10.1029/2000JD900719, 2001.

Trebs, I., Lara, L. L., Zeri, L. M. M., Gatti, L. V., Artaxo, P., Dlugi, R., Slanina, J., Andreae, M. O., and Meixner, F. X.: Dry and wet deposition of inorganic nitrogen compounds to a tropical pasture site (Rondônia, Brazil), Atmos. Chem. Phys., 6, 447469, doi:10.5194/acp-6-447-2006, 2006.

UNC: SMOKE V2.4 User's Manual, available at: http://www. cmascenter.org/smoke/documentation/2.4/html/ (last access: 25 December 2013), 2009.

Van Bremen, N., Burrough, P. A., Velthorst, E. J., van Dobben, H. F., de Wit, T., Ridder, T. B., and Reijnders, H. F. R.: Soil acidification from atmospheric ammonium sulphate in forest canopy throughfall, Nature, 299, 548-550, doi:10.1038/299548a0, 1982.

Van der Hoven, I.: Deposition of particles and gases, Meteorology and Atomic Energy, in: Meteorology and Atomic Energy, edited by: Slade, D., US Atomic Energy Commission, 202-208, 1968.

Vet, R., Li, S.-M., Beaney, G., Belzer, W., Chan, E., Dann, T., Friesen, K., Hayden, K., Hou, A., Iqbal, S., Jones, K., Leithead, A., Liggio, J., Makar, P., Narayan, J., Ro, C.-U., Shaw, M., Sukloff, B., Vingarzan, R., and Qiu, W.: Characterization of ambient ammonia, PM and regional deposition across Canada, Chapter 6, in: Environment Canada. The 2008 Canadian Atmospheric Assessment of Agricultural Ammonia, Environment Canada, Gatineau, QC, Canada, 93-147, 2008.

Vieno, M., Dore, A. J., Stevenson, D. S., Doherty, R., Heal, M. R., Reis, S., Hallsworth, S., Tarrason, L., Wind, P., Fowler, D., Simpson, D., and Sutton, M. A.: Modelling surface ozone during the 2003 heat-wave in the UK, Atmos. Chem. Phys., 10, 7963-7978, doi:10.5194/acp-10-7963-2010, 2010

Wen, D., Lin, J. C., Meng, F., Gbor, P. K., He, Z., and Sloan, J. J.: Quantitative assessment of upstream source influences on total gaseous mercury observations in Ontario, Canada, Atmos. Chem. Phys., 11, 1405-1415, doi:10.5194/acp-11-1405-2011, 2011.
Wen, D., Lin, J. C., Millet, D. B., Stein, A. F., and Draxler, R. R.: A backward-time stochastic Lagrangian air quality model, Atmos. Environ., 54, 373-386, doi:10.1016/j.atmosenv.2012.02.042, 2012.

Wen, D., Lin, J. C., Zhang, L., Vet, R., and Moran, M. D.: Modeling atmospheric ammonia and ammonium using a stochastic Lagrangian air quality model (STILT-Chem v0.7), Geosci. Model Dev., 6, 327-344, doi:10.5194/gmd-6-327-2013, 2013.

Wesely, M. L.: Parameterization of surface resistance to gaseous dry deposition in regional-scale numerical models, Atmos. Environ., 23, 1293-1304, doi:10.1016/0004-6981(89)90153-4, 1989.

Wichink Kruit, R. J., Van Pul, W. A. J., Sauter, F. J., Van den Broek, M., Nemitz, E., Sutton, M. A., Krol, M., and Holtslag, A. A. M.: Modeling the surface-atmosphere exchange of ammonia, Atmos. Environ., 44, 945-957, doi:10.1016/j.atmosenv.2009.11.049, 2010.

Wichink Kruit, R. J., Schaap, M., Sauter, F. J., van Zanten, M. C., and van Pul, W. A. J.: Modeling the distribution of ammonia across Europe including bi-directional surface-atmosphere exchange, Biogeosciences, 9, 5261-5277, doi:10.5194/bg-9-52612012, 2012.

Wu, Y., Walker, J., Schwede, D., Peters-Lidard, C., Dennis, R., and Robarge, W.: A new model of bi-directional ammonia exchange between the atmosphere and biosphere: ammonia stomatal compensation point, Agr. Forest Meteorol., 149, 263-280, doi:10.1016/j.agrformet.2008.08.012, 2009.

Wu, Z., Wang, X., Chen, F., Turnipseed, A. A., Guenther, A. B., Niyogi, D., Charusombat, U., Xia, B., Munger, J. W., and Alapaty, K.: Evaluating the calculated dry deposition velocities of reactive nitrogen oxides and ozone from two community models over a temperate deciduous forest, Atmos. Environ., 45, 26632674, doi:10.1016/j.atmosenv.2011.02.063, 2011.

Wu, Z., Wang, X., Turnipseed, A. A., Chen, F., Zhang, L., Guenther, A. B., Karl, T., Huey, L. G., Niyogi, D., Xia, B., and Alapaty, K.: Evaluation and improvements of two community models in simulating dry deposition velocities for peroxyacetyl nitrate (PAN) over a coniferous forest, J. Geophys. Res.-Atmos., 117, D04310, doi:10.1029/2011JD016751, 2012.

Zhang, L., Gong, S., Padro, J., and Barrie, L.: A size-segregated particle dry deposition scheme for an atmospheric aerosol module, Atmos. Environ., 35, 549-560, doi:10.1016/S13522310(00)00326-5, 2001.

Zhang, L., Moran, M., Makar, P., Brook, J., and Gong, S.: Modelling gaseous dry deposition in AURAMS: a unified regional air-quality modelling system, Atmos. Environ., 36, 537-560, doi:10.1016/S1352-2310(01)00447-2, 2002.

Zhang, L., Brook, J. R., and Vet, R.: A revised parameterization for gaseous dry deposition in air-quality models, Atmos. Chem. Phys., 3, 2067-2082, doi:10.5194/acp-3-2067-2003, 2003.

Zhang, L., Wright, L. P., and Asman, W. A. H.: Bi-directional airsurface exchange of atmospheric ammonia: a review of measurements and a development of a big-leaf model for applications in regional-scale air-quality models, J. Geophys. Res., 115 , D20310, doi:10.1029/2009JD013589, 2010. 